\title{
Has mobile phone technology aided the growth of agricultural productivity in sub-Saharan Africa?
}

\begin{tabular}{|c|c|}
\hline $\begin{array}{l}\text { Authors: } \\
\text { Omotomiwa ( } \\
\text { Adenubi i, } \\
\text { Omphile Temo } \\
\text { Isiaka Abdulal }\end{array}$ & $\begin{array}{l}\text { Tommy) } \\
\mathrm{So}^{1} \text { (1) } \\
\mathrm{eem}^{2} \text { (D) }\end{array}$ \\
\hline $\begin{array}{l}\text { Affiliations: } \\
\text { 'UNE Business } \\
\text { University of } \\
\text { Armidale, Aus }\end{array}$ & $\begin{array}{l}\text { School, } \\
\text { Jew England, } \\
\text { tralia }\end{array}$ \\
\hline $\begin{array}{l}{ }^{2} \text { University of } \\
\text { Reading, Unite }\end{array}$ & $\begin{array}{l}\text { Reading, } \\
\text { d Kingdom }\end{array}$ \\
\hline $\begin{array}{l}{ }^{3} \text { Centre for Ag } \\
\text { Phambook En } \\
\text { Ondo State, N }\end{array}$ & $\begin{array}{l}\text { ricbusiness, } \\
\text { erprise, } \\
\text { geria }\end{array}$ \\
\hline $\begin{array}{l}\text { Correspondin } \\
\text { Tommy Adenu } \\
\text { Tadenubi1@g }\end{array}$ & $\begin{array}{l}\text { gauthor: } \\
\text { bi, } \\
\text { mail.com }\end{array}$ \\
\hline $\begin{array}{l}\text { Dates: } \\
\text { Received: } 19 \mathrm{~J} \\
\text { Accepted: } 30 \\
\text { Published: } 25\end{array}$ & $\begin{array}{l}\text { une } 2020 \\
\text { Aug. } 2021 \\
\text { Nov. } 2021\end{array}$ \\
\hline $\begin{array}{l}\text { How to cite th } \\
\text { Adenubi, O., T } \\
\text { Abdulaleem, I. } \\
\text { mobile phone } \\
\text { aided the gron } \\
\text { agricultural pr } \\
\text { sub-Saharan A } \\
\text { African Journa } \\
\text { and Managem } \\
24(1) \text {, a3744. } \\
\text { org/10.4102/s } \\
\text { v24i1.3744 }\end{array}$ & $\begin{array}{l}\text { is article: } \\
\text { emoso, O. \& } \\
\text {, 2021, 'Has } \\
\text { technology } \\
\text { th of } \\
\text { oductivity in } \\
\text { frica?', South } \\
\text { I of Economic } \\
\text { ent Sciences } \\
\text { tttps://doi. } \\
\text { ajems. }\end{array}$ \\
\hline $\begin{array}{l}\text { Copyright: } \\
\text { C 2021. The A } \\
\text { Licensee: AOSI } \\
\text { is licensed und } \\
\text { Creative Comn } \\
\text { Attribution Lic }\end{array}$ & $\begin{array}{l}\text { uthors. } \\
\text { IS. This work } \\
\text { ler the } \\
\text { nons } \\
\text { ense. }\end{array}$ \\
\hline Read online: & \\
\hline 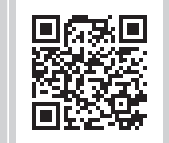 & $\begin{array}{l}\text { Scan this QR } \\
\text { code with your } \\
\text { smart phone or } \\
\text { mobile device } \\
\text { to read online. }\end{array}$ \\
\hline
\end{tabular}

Background: A recent increase in the adoption of mobile phone technology generated a great deal of interest and optimism regarding its effect on economic development in sub-Saharan Africa (SSA), particularly on the enhancement of agricultural development.

Aim: In this study the impact of mobile phone technology on agricultural productivity in SSA is examined.

Setting: The empirical assessment uses a panel data set covering 41 countries over a period of 25 years.

Methods: We employed an econometric approach and panel data covering 41 countries and a 25 year-period (1990-2014) to investigate the effect of the adoption of mobile phone technology and other socio-economic variables on agricultural total factor productivity (TFP). The use of regression analyses allowed us to estimate and measure the contribution of certain variables to agricultural TFP growth in SSA.

Results: The results show that the uptake of mobile phone technology had a positive effect on agricultural TFP growth in SSA.

Conclusion: Mobile phone technology has been established to be one of the drivers of agricultural productivity in SSA.

Implication: The implications of this study are that governments, NGOs, and businesses working on improving agricultural productivity and food security in SSA need to continue endorsing mobile technology as a means to improve agricultural productivity.

Keywords: agriculture; SSA; mobile phone technology; total factor productivity; economic growth; population; agricultural productivity; technical efficiency.

\section{Introduction}

Recent technological advancements in information and communication technology (ICT) are having a significant impact on the growth and socio-economic development of businesses, industries, and countries across the world (FAO 2017). There is increasing evidence that firms which adopt ICT technologies are more likely to foster important organisational changes within their firms, with such changes having a significant impact on their performance and business growth (Brynjolfsson \& Hitt 2000). Information and communication technology enabled firms in advanced economies to become more productive, reduce costs, and improve their understanding of the markets they serve. For example, ICT applications such as the Internet of Things, Big Data and Cloud Computing allow a large volume of information and data to be generated (data-driven and data-enabled), which in turn is used by scientists and farmers to provide timely analysis and advice, enabling farmers to achieve better yields by optimising their crop and livestock management, as well as resource reallocation (Wolfert et al. 2017).

On the other hand, developing countries, particularly in sub-Saharan Africa (SSA), continue to experience a vast infrastructure deficit which constrains their economic growth. Surprisingly, although still lagging behind in terms of infrastructure investment, the region experienced a remarkable increase in the adoption of mobile phone technology across the region (Aker \& Mbiti 2010). The number of mobile phone users has grown faster in Africa than in any other region in the world, starting with just over 10000 subscriptions in 1990, increasing to 1.3 million by 2000 and hitting 770 million in 2016 (World Bank 2017).

Sub-Saharan Africa continues to depend heavily on agriculture, in that the sector contributes on average about $15 \%$ to the total GDP (World Bank 2017), employs over 50\% of the rural population, 
being the primary source of livelihood for $10 \%-25 \%$ of the urban population (Organization for Economic Co-operation and Development [OECD] \& Food and Agriculture Organization of the United Nations [FAO] 2017). However, despite the importance of the sector to the economy and people of SSA, there is evidence that relative to other developing regions (Asia and Latin America), the agriculture performance in the SSA region continues to lag behind, and one of the contributing factors to this poor performance is its low agricultural productivity.

There are several reasons identified in the literature for why SSA agriculture continues to perform poorly and lag behind the other regions. These include: low investment in infrastructure and agricultural research and development; slow reform of agricultural policies; low levels of education; poor weather conditions; poor trade reforms; and urbanisation (increased rural-urban migration) which have all contributed to low productivity. Therefore, improvement in agricultural productivity is considered essential for increasing the desirable agricultural output to meet the demands for food and raw materials arising out of a steady population growth (Coelli \& Rao 2005).

Thus, the recent increase in the adoption of ICT technologies, such as mobile phone technology, provides opportunities for improving agricultural productivity in developing regions, for example, mobile phones have the potential to reduce information and coordination costs, which enables greater farmer participation in commercial agriculture (FAO 2017). Mobile phone technology could help smallholder farmers to access critical inputs such as credit, seeds, fertiliser and herbicides which might help improve productivity and food security. The development possibilities opened by the rapid increase in mobile phone technology have also been recognised by private, public and non-government organisations. These include: e-Agriculture Community of Practice (FAO), InfoDev (World Bank Group) and ICT-AGRI research on the Internet of Things applications with a focus on precision farming applications on smaller farms.

However, despite indications of the impact of mobile phone technology on economic development (including in agriculture), there is limited empirical evidence of the impact that mobile phone technology has on agricultural productivity, particularly in developing countries. Thus, the purpose of this study is to provide empirical evidence of whether the recent increase in the uptake of mobile phone technology has had any effect upon agricultural productivity in SSA. Specifically, we seek answers to the following questions:

- To what extent has mobile phone technology helped in improving agricultural productivity?

- Across different income groups, to what extent does the impact of mobile phone technology on agriculture vary?

There is a substantial amount of material on the topic of agricultural productivity in SSA (Block 1994; Fuglie \& Rada
2012; Lusigi \& Thirtle 1997; Thirtle, Hadley \& Townsend 1995). In different studies, various approaches are employed to estimate agricultural TFP growth in SSA, with different sample sizes, methods, and time periods. The majority of these studies conclude that there was a slow growth in agricultural TFP in the 1960s, negative growth in the 1970s, followed by a slow recovery in the 1980s and subsequent years. Overall TFP growth has been below $1 \%$ annually since 1961 (Fuglie \& Rada 2012). Fuglie and Rada (2012) employed multivariate regression analysis to examine factors, hypothesised to have an effect upon agricultural productivity, these included: investment in research and development; input subsidies; commodity price intervention; human capital development; investment in the education and health of the labour force; infrastructure investment; and political stability. Heshmati and Kumbhakar (2011) observed that investment in agricultural research through technical change provided a mechanism for TFP growth, while the other variables provided an enabling environment for economic growth by, for example, facilitating the access farmers have to new technologies and markets.

This paper fills a gap in the literature by looking at the impact of mobile phone technology on agricultural productivity in SSA, across different countries over a period of 25 years. The study covers a broader geographical scope and a longer period of time, providing a high degree of robustness in the results. The study also contributes to literature by examining the impact of mobile technology on agricultural productivity, specifically, rather than addressing broader economic growth, or singling out an agricultural product. The relatively long time series data employed in the study has the ability to measure the effect of pre- and post-mobile phone technology on agricultural productivity, thus allowing multi-temporal and multi- spatial comparisons. The results of the study could help policymakers make the case to extend mobile phone coverage to states, regions and provinces where it is currently lacking.

The remainder of this paper is organised as follows. In section 2 , studies on the impact of mobile phone technology (and other ICT technologies) on agriculture are reviewed. In section 3 , the data and sources of data are described. In section 4, empirical strategy and data used in the empirical analysis are described. Section 5 presents the results and the main empirical findings. Finally, section 6 presents the summary and conclusion.

\section{Literature review: Mobile phone technology (information and communication) and agricultural development}

The rapid growth of telecommunications in developing countries, particularly the uptake of mobile technology and coverage, is creating a great interest in its potential impact on agricultural development. It has long been recognised that there exists a positive relationship between investing capital 
in infrastructure such as communication facilities and agricultural development (Antle 1983).

In recent times, empirical evidence of the impact of mobile technology (ICT) on agricultural development, has been growing (FAO 2017). Table 1 provides a summary of some of these studies. In a study by Lum (2011), the impact of mobile phones on economic development and growth through econometric analysis, using panel data for 182 countries, is examined. The conclusion is that there is a positive relationship between mobile phone and economic development in developing countries; therefore, an increase in the number of mobile phone users leads to an increase in real GDP per capita.

Nnadi et al. (2012) observed that ICT is a medium that has radically improved interaction around the globe, implying the need to create a strong link characterised by the impeccable flow of information; this is because ICT improves the quality and timing of information between extension agents and farmers, rather than passing information through a long bureaucratic chain. Employing data, collected through focus group discussions and interviews with fishermen and farmers across five states in India, Mittal, Gandhi and Tripathi (2010) remarked that mobile phones enabled the respondents to receive timely information, assisting them to increase their yields. In Africa, generally, a large amount of research has shown that an enabling environment relying on free communication and ICT, among other factors, is required for long-term social and economic development (Perez-Estebanez et al. 2017).

One of the highly cited papers on this topic, is a study by Aker and Mbiti (2010) which examined the evolution of mobile coverage and its adoption in SSA, as well the main channels through which mobile phones could enhance economic outcomes and improve economic development. The report concluded that mobile phones have the potential to benefit consumer and producer welfare, and perhaps broaden economic development. Using secondary market data on grains from Niger, Aker (2008) examined the impact of the use of mobile phones on the market performance of grain. It is concluded that the use of mobile phone technology reduced dispersion of grain prices across domestic and cross-border markets. Furthermore, mobile phones helped traders to reduce search costs, have better access to market information and reduce inefficiency in moving goods across markets.

In Malawi, Katengeza et al. (2011) assessed the drivers of the adoption by smallholder farmers of mobile phone technology for agricultural marketing. Asset ownership was found to play a critical role in enhancing the acceptance of mobile phone technology. In the study, the need is emphasised to improve farmers' access to mobile phones for agricultural marketing. Moreover, it recommended the need to foster a collaborative relationship between government and network operators which should reduce calling tariffs to enhance use, while investment in infrastructure must be increased as well.

Despite a growing number of studies on the impact of mobile phone technology on different aspects of agricultural development, there is to the best of our knowledge, no study that has evaluated the impact of mobile phone technology on agricultural productivity in SSA, extensively covering countries in multiple periods. This study contributes to the literature by examining the impact of mobile phones on agricultural productivity. Thus, rather than addressing broader economic growth, or singling out an agricultural product, we focus on the agricultural productivity. The results of the study could help policymakers make the case to extend mobile phone coverage to states, regions or provinces where it is currently lacking. This study aims to contribute to the existing literature and create a background for further research into the role of mobile phones in the agricultural sector in SSA and elsewhere.

TABLE 1: Selected empirical studies on the impact of mobile (information and communication) technology on agriculture.

\begin{tabular}{|c|c|c|c|c|}
\hline Study & Study site & Type of ICT used & Purpose of ICT used for & Effects of intervention \\
\hline Aker (2008) & Niger & Mobile phones & Market information & $\begin{array}{l}\text { - Reduction in search costs } \\
\text { - Reduced grain-price dispersion across markets by a } \\
\text { minimum of } 6.5 \%\end{array}$ \\
\hline Svenson \& Yanagizaw (2009) & Uganda & Radio & Market information & $\begin{array}{l}\text { - Better bargaining power } \\
\text { - Higher farm-gate prices }\end{array}$ \\
\hline $\begin{array}{l}\text { Barrios, Joseph Ryan and } \\
\text { Daquis (2011) }\end{array}$ & Southern Philippines & Internet and optical media & $\begin{array}{l}\text { Information on agricultural } \\
\text { and farming technologies }\end{array}$ & $\begin{array}{l}\text { - Higher farm income } \\
\text { - Better living conditions than that of control group }\end{array}$ \\
\hline Fengying et al. (2011) & Ningxia, China & $\begin{array}{l}\text { Internet, Internet protocol } \\
\text { TV and Video }\end{array}$ & Village information centre & $\begin{array}{l}\text { - Capability building } \\
\text { - Improved income and livelihoods }\end{array}$ \\
\hline Rizvi (2011) & India & Mobile phone & Advisory service & $\begin{array}{l}\text { - Annual average income was } 37 \% \text { higher than that of } \\
\text { control group } \\
\text { - Increase productivity and disease control }\end{array}$ \\
\hline Muto and Yamano (2009) & Uganda & Mobile phone & Exposed to mobile network & $\begin{array}{l}\text { - Market participation of farmers who are in remote } \\
\text { areas and production of perishable crops }\end{array}$ \\
\hline Lokanathan et al. (2011) & Sri Lanka & $\begin{array}{l}\text { SMS, Internet } \\
\text { WAP, Unstructured } \\
\text { Supplementary Service Data } \\
\text { and Telephone }\end{array}$ & Price information & $\begin{array}{l}\text { - Farmers were able to increase income by about } \\
\text { USD0.045-0.09 per kg of their produce } \\
\text { - Behavioural changes that aided farmers' ability to } \\
\text { coordinate supply and demand for agricultural } \\
\text { produce, given price signals }\end{array}$ \\
\hline Raj et al. (2011) & Nagapattinam, India & $\begin{array}{l}\text { SMS \& Interactive voice } \\
\text { response system, web pages }\end{array}$ & $\begin{array}{l}\text { Crop cultivation and nutrient } \\
\text { management practices }\end{array}$ & $\begin{array}{l}\text { - Significant reduction in cost of cultivation } \\
\text { - Net income of farmers grew by about } 1.5 \%-2 \% \text {. }\end{array}$ \\
\hline
\end{tabular}

Source: Asenso-Okyere, K. \& Mekonnen, D.A., 2012, 'The importance of ICTs in the provision of information for improving agricultural productivity and rural incomes in Africa', African Human Development Report, UNDP Sponsored research Series.

ICT, information and communication technology. 


\section{Data}

\section{Data sources and variable}

The description of the production input and output variables used in this study are discussed in Table 2, whilst their summary statistics are presented in Table 3

\section{Descriptive statistics}

The average for the 41 countries during the 25-year period over which the data were collected was 2.92 million worth of agricultural output, with an average harvested area of 4816.18 hectares of land, employing an average of 4.2 million persons in labour. There was an average fertiliser application of 54327.5 metric tonnes of active ingredients (nitrogen, potassium and phosphorus). Output during the period was highly variable, ranging from $\$ 34.8$ million to over $\$ 40$ billion. Also, there was an average of 19.13 mobile phone subscriptions per 100 people, with a variability ranging from 0 to 171.38 subscriptions per 100 people. Table 2 provides a brief description of the variables employed in the study, while table 3 provides a summary of the descriptive statistics.

\section{Methodology}

To achieve the objective of this study, two main empirical approaches were used. Firstly, agricultural TFP was estimated following an approach by Fuglie and Rada (2013). According to Coelli et al. (2005:62), 'in the presence of multiple outputs and inputs, total factor productivity may be defined as a ratio of aggregate output produced relative to aggregate input used'. In other words, the growth in the agricultural output of a country is dependent on the factors of production (land, labour, capital, materials), as well as increases in TFP - improvements in

TABLE 2: Production and productivity variables.

Variable

Data

Agricultural land

The data for this variable were obtained from FAO. Data on agricultural production include those on gross and net production values, in constant international US dollars, as well as gross production values, in constant current US\$ and local currency units; for various food and agriculture commodities and aggregates thereof, expressed in both total value and value per capita.

The data for this variable were obtained from the United States Department of Agriculture (USDA). It defines agricultural land as the area under permanent (perennial) and annual crops, as well as permanent pasture. Cropland (permanent and annual) is further subdivided into rain-fed areas and areas equipped for irrigation. Another reason for the preference of the FAO total harvested area for all crops, is that the FAO cropland (arable land and permanent cropland) underestimates the growth in the actual area of crop cultivation, at least for some countries in SSA (Fuglie \& Rada 2013).

Agricultural labour The data for agricultural labour were obtained from the USDA (which the USDA sourced from the FAO farm labour estimates). It defines agricultural labour or farm labour, based on the FAO definition, which is the total number of adults (males and females) who are economically active in agriculture. These FAO estimates were used for all countries except Nigeria, where labour estimates are derived from extrapolating FAO data for 1961-1966, assuming a $2 \%$ annual growth rate (this follows Fuglie and Rada [2013]).

Exchange rate The data on exchange rate measures the rate of exchange between the relevant currency and a unit of the dollar. The data represent the exchange rate as stipulated by the authorities. It is computed as a yearly average.

Fertiliser The data for fertiliser were obtained from the USDA. It defines fertiliser as the amount of inorganic nutrients applied to agricultural land annually, measured as metric tonnes of nitrogen, phosphorus and potassium ( $\mathrm{N}, \mathrm{P} O \mathrm{O}$ and $\mathrm{K} \mathrm{O}$ ). United States Department of Agriculture sourced the data from the International Fertilizer Association, except for small countries, where data were sourced from the FAO.

Value of livestock

FAO (Chilonda \& Otte 2006) define the principal species of livestock as cattle, buffaloes, sheep, goats, pigs, chickens, ducks, turkeys and other poultry. These include donkeys, horses, mules and camels. The Food and Agriculture Organization provides livestock unit coefficients based on the weight of animals, that makes it possible to aggregate different livestock units. In producing a unit of livestock, data on donkeys, camels, cattle, chicken, goats, horses, mules, pigs and sheep were collected from the FAO and aggregated for each country, using these coefficients.

Mobile phone cellular

The World Bank collects data from the International Telecommunication Union and World Telecommunication/ICT Development Report databases. The World Bank defines mobile cellular telephone subscriptions as subscriptions to a public mobile telephone service that provide access to the public-switched telephone network (PSTN) using cellular technology. The indicator includes (and is split into) the number of post-paid subscriptions and the number of active pre-paid accounts (i.e. used during the last 3 months). The indicator applies to all mobile cellular subscriptions offering voice communications. The use of mobile phones, according to the World Bank, did not start in SSA until the beginning of the 1990 s, and has grown significantly over the years, especially in the $2000 \mathrm{~s}$, when mobile subscriptions went from about 13 million in 2000 to about 770 million subscriptions in 2016 , coverin, the impact and effect of this widespread communication tool on agricultural productivity in SSA.

Human capital index

The human capital index was sourced from the Penn World Tables and is based on years of schooling and return to education. The Human Capital Index quantifies the contribution of education to the productivity of the next generation of workers.

Animal feed

The data for this variable were obtained from the USDA. It defines animal feed as the total crop production (with the exclusion of fodder), animal and fish products used for feeding, measured in tonnes of dry matter (DM). United States Department of Agriculture sources these dat from the FAO commodity balance sheets.

HIV adult (\% prevalence HIV adult) The data for adult HIV prevalence were collected from the World Bank. As defined by the World Bank, the prevalence of HIV refers to the

(\% prevalence age $15-49)$ percentage of people, ages 15-49, who are infected with HIV. This pandemic has had an adverse effect on the growth of SSA's economy. Dixon, McDonald and Roberts (2002) report that HIV/AIDS affected economic output negatively by $2 \%-4 \%$.

Credit to agriculture The data for agricultural credit availability were collected from the FAOSTAT. It defines credit to agriculture as loans provided by the commercia or private banking sector to producers in agriculture, forestry and fisheries, also including household producers, agribusiness and co-operatives. or private banking sector to producers in agriculture, forestry and fisheries, also including household producers, agribusiness and co-operative
The FAO indicates that the three subsectors of agriculture, forestry and fishing are disaggregated in some countries though not in others.

Research expenditure The data on the research expenditure variable were obtained from FAOSTAT, sourced from Agricultural Science and Technology Indicators (ASTI). The Agricultural Science and Technology Indicators collect primary time series data on the agricultural research capacity and spending levels through national surveys. Data collection is done via country focal points distributing survey forms to agencies engaging in agricultural research. The data for the safety and rule of law variable were obtained from the $2017 \mathrm{MO}$ Ibrahim Index of African Governance (IIAG). Features that are
identified in this index are the independence of the judiciary from the influence of external factors, the ability of the judiciary to autonomously review and interpret existing laws, legislations and policy, and the process of appointing and removing national-level judges.

Infrastructure

The data for the infrastructure variable were obtained from the $2017 \mathrm{MO}$ Ibrahim Index of African Governance (IIAG). Features that are identified are the extent to which the public is satisfied with government's maintenance of roads and bridges, the adequacy of the rail network for business needs and the quality of air transport with aviation safety.

Ratio of refugees to total population The data for ratio of refugees to the total population were obtained by dividing the number of refugees in each country by its total population. The total population data were sourced from the FAO, while those of the refugees were sourced from the World Bank. According to the World Bank (2017), refugees are people who are recognised as 'refugees under the 1951 Convention Relating to the Status of Refugees, or its 1967 Protocol, the 1969 Organization of African Unity Convention Governing the Specific Aspects of Refugee Problems in Africa, people recognised as refugees in accordance with the UNHCR (United Nations High Commissioner for Refugees) statute, people granted refugee-like humanitarian status and people provided with temporary protection' and generally covers people who have lost their homes and means of livelihood.

FAO, Food and Agriculture Organization; USDA, United States Department of Agriculture; SSA, sub-Saharan Africa; HIV, human immunodeficiency virus; ICT, information and communication technology. 
TABLE 3: Summary of descriptive statistics.

\begin{tabular}{|c|c|c|c|c|}
\hline Variable name & Mean & SD & Minimum & Maximum \\
\hline Output (1000 Int. US dollars) & 2920378.80 & 152871.80 & 34816.90 & 40358467 \\
\hline Agricultural Productivity (TFP) & 94.3626 & 16.76876 & 49.80483 & 163.9567 \\
\hline Agricultural Land (ha) & 4816.20 & 223.8 & 72.9 & 52031.80 \\
\hline Agricultural Labour (persons) & 4252.10 & 172.7 & 108 & 38936.00 \\
\hline Livestock (head) & 8537.80 & 406.9 & 14.6 & 82856.70 \\
\hline Capital (fixed capital \$US) & 177.3 & 10.3 & 0.3 & 2357.00 \\
\hline Mobile (subscriptions/100 people) & 19.1 & 1 & 0 & 171.4 \\
\hline HIV ( $\%$ of total population) & 5.6 & 0.2 & 0.1 & 30 \\
\hline Human capital (years of schooling) & 1.6 & 0 & 1 & 2.8 \\
\hline Agricultural credit (\$US millions) & 179.9 & 15.6 & 0 & 3020.50 \\
\hline Research Expenditure (2011 PPP\$US) & 67.3 & 7 & 0.2 & 967.7 \\
\hline Safety law (index) & 52.7 & 0.5 & 7.6 & 84.5 \\
\hline Infrastructure (index) & 32.7 & 0.5 & 1.7 & 69.1 \\
\hline
\end{tabular}

SD, standard deviation; HIV, human immunodeficiency virus; PPP, Purchasing power parities.

the efficiency of an aggregate bundle of inputs (Fuglie \& Rada 2013). Following the estimation of TFP, panel data regression models were used to investigate the effect of several macro-economic variables, including mobile phone technology on agricultural TFP growth in 41 SSA countries for the 1990-2014 period.

\section{Measuring agricultural total factor productivity indexes}

In order to estimate the TFP for the countries by adopting an approach from Fuglie and Rada (2013), the following CobbDouglas agricultural production function was used:

$$
\operatorname{In}\left(Y_{t}\right)=\operatorname{In}\left(A_{0}\right)+\Sigma_{j}\left[\varnothing_{j} \operatorname{In}\left(Z_{j t}\right)+\theta_{j} \operatorname{In}\left(X_{j t}\right)\right]+\varepsilon_{t}
$$

Where $\ln$ represents natural logarithms; $Y_{t}$ is output at time $t$; $\mathrm{A}_{t}$ is the productivity index at time $t\left(\mathrm{~A}_{0}\right.$ is the base-period productivity); $X_{j t}$ is the measured quantity of 'the effective' quantity of input $j$ (in constant quality units); $Z_{j t}$ is a vector of quality shifters in input $j$, which may vary over time; $\varnothing_{j}$ is the elasticity in output with respect to input quality and the residual $\varepsilon_{t}$ includes TFP growth and random fluctuations in output:

$$
\begin{aligned}
\operatorname{In}\left(\widehat{T F P}_{t}\right)= & \operatorname{In}\left(Y_{t}\right)-\operatorname{In}\left(\hat{Y}_{t}\right)=\operatorname{In}\left(Y_{t}\right)- \\
& \left\{\operatorname{In}\left(\hat{A}_{0}\right)+\Sigma_{j}\left[\widehat{\varnothing}_{J} \operatorname{In}\left(Z_{i t}\right)+\hat{\theta}_{J} \operatorname{In}\left(X_{j t}\right)\right]\right\}
\end{aligned}
$$

Given Equation (2), an index for TFP is derived which is the difference between current output and predicted output without technical change where $\operatorname{TFP}_{t}$ is simply $\operatorname{TFP}_{\mathrm{t}} e^{u t}$ and $\hat{A}_{0^{\prime}}$ $\hat{A}_{0}, \hat{\theta}_{0}$ are estimated values from Equation (2):

$T F P_{t}=\frac{A_{t}}{A_{0}}=\left(S_{t}^{\alpha_{1}}\right)\left(e^{\alpha_{2} w_{t}}\right)$

[Eqn 3]

where $S_{t}$ is local Research and Developmemnt (R\&D) stock; $W_{t}$ is a vector of other variables, affecting the rate of productivity growth, including technology spillover from outside sources and the enabling environment for technology diffusion; $\alpha_{1}$ is the elasticity of output with respect to local $R \& D$ stock (research elasticity); $\alpha_{2}$ is the vector of coefficients on $W_{t}$ variables.

From Equation (3) and taking natural logs, we arrive at:

$$
\operatorname{In}\left(\widehat{T F P}_{t}\right)=\alpha_{1} \operatorname{In}\left[S_{t}\right]+\alpha_{2} W_{t}+u_{t}
$$

The regression provides estimates of the parameters $\alpha_{1}$ and $\alpha_{2}$ :

$\operatorname{In}\left(\frac{Y_{t c}}{X_{j t c}}\right)=\operatorname{In}\left(A_{0}\right)+\Sigma j \varnothing_{j} \operatorname{In}\left(Z_{j t c}\right)+\Sigma_{j=1}^{j-1} \theta_{j}\left(\frac{X_{j t}}{X_{j t c}}\right)+\eta_{c}+\varepsilon_{t c}$ [Eqn 5]

where $\eta_{c}$ is a vector of country-specific random effects.

\section{Total factor productivity indexes}

Given the estimates of the parameters $\widehat{\varnothing}_{j}, \widehat{\varnothing}_{j}$ from Equation (5), growth in TFP over time is calculated for each country as:

$\operatorname{In}\left(\frac{\widehat{T F P}_{t c}}{\widehat{T F P}_{o c}}\right)=\operatorname{In}\left(\frac{Y_{t c}}{Y_{o c}}\right)-\Sigma_{j}\left[\widehat{\varnothing}_{j} \operatorname{In}\left(\frac{Z_{j t c}}{Z_{j o c}}\right)+\widehat{\varnothing}_{j} \operatorname{In}\left(\frac{X_{j t c}}{X_{j o c}}\right)\right]$ [Eqn 6]

Therefore, the changes in TFP simply calculated by taking the difference between growth in aggregate output and aggregate inputs (adjusted for quality) for the individual country. By setting $\widehat{T F P} O c=100$ as the base year, agricultural TFP indexes for all the countries in the region is derived. Using this approach, the indexes of agricultural TFP in the 41 countries for each year between 1991 and 2014 was estimated (Figure 1 provides average TFP scores estimated using this approach).

\section{Determinants of productivity growths}

Fuglie and Rada (2013) investigated the effects of a number of variables in agricultural Total Factor Productivity growth (TFP) in sub-Saharan Africa (SSA). The authors considered the effects of national investments in agriculture, international 
agricultural research, 'enabling' variables for the diffusion of improved technologies, including farmer schooling and health (human capital), governance, and infrastructure. The authors further considered the effect of HIV/AIDS on the adult population, the incidence of armed conflict and nominal rate of assistance to agriculture on TFP growth. These guided our choice of variables (control variables) in estimating the impact on mobile technology on agricultural TFP growth in (SSA).

Using a similar approach to Fuglie and Rada (2013), we employed panel data to investigate the effects of a number of variables on agricultural TFP growth:

$$
\begin{aligned}
\log (\text { TFP })= & \alpha_{0}+\alpha_{1} \text { REFPROP }+\alpha_{2} \text { MOBILE }+\alpha_{3} H I V+\alpha_{4} H C+ \\
& \alpha_{5} C R E D I T+\alpha_{6} \text { RESESP }+\alpha_{7} I N F R A+\alpha_{8} S A F E L A W+ \\
& \alpha_{9} \log (\text { EXCHANGERATE })+V_{i}
\end{aligned}
$$

Where TFP represents Total Factor Productivity; REFPROP represents Refugee/Population ratio; Mobile represents Mobile phone subscriptions/100 persons; HIV represents percentage of the total population (15-49) having the virus; HC represents years of schooling and return to education; CREIT represents Agricultural Credits; RESESP represents Agricultural Research Capacity and Expenditure; INFRA represents the satisfaction of the public with basic infrastructural amenities; SAFELAW represents safety and rule of law; EXCHANGERATE denotes the rate at which the US dollar exchanges for the local currencies of countries included in our sample. We take the logarithmic transformation of exchange rate to stabilise the variance of our data. $\alpha_{0}-\alpha_{9}$ are vectors of unknown parameters to be estimated and $V_{i}$ represents random noise.

\section{Results and discussion Agricultural productivity growth}

Figure 1 shows that the average level of agricultural productivity in sub-Saharan Africa is relatively high. Although Cameroon had the lowest average agricultural productivity between 1990 and 2014; the country's average agricultural productivity was as high as 73.87 during this period. Meanwhile, Uganda had the highest average agricultural productivity at 129.74 .

\section{Baseline econometric analysis}

The baseline regression model is estimated, using the Least Squares Dummy Variables (LSDV) method. Results are presented in Tables 4-6. This section presents the results obtained from our baseline regression model using the LSDV technique. Spherical disturbances are ensured using the Driscoll-Kraay standard errors (Driscoll \& Kraay 1998). Table 4 (column 1) provides the results obtained, using the LSDV method. The result suggests that agricultural productivity rises by $12.7 \%$, with one additional person

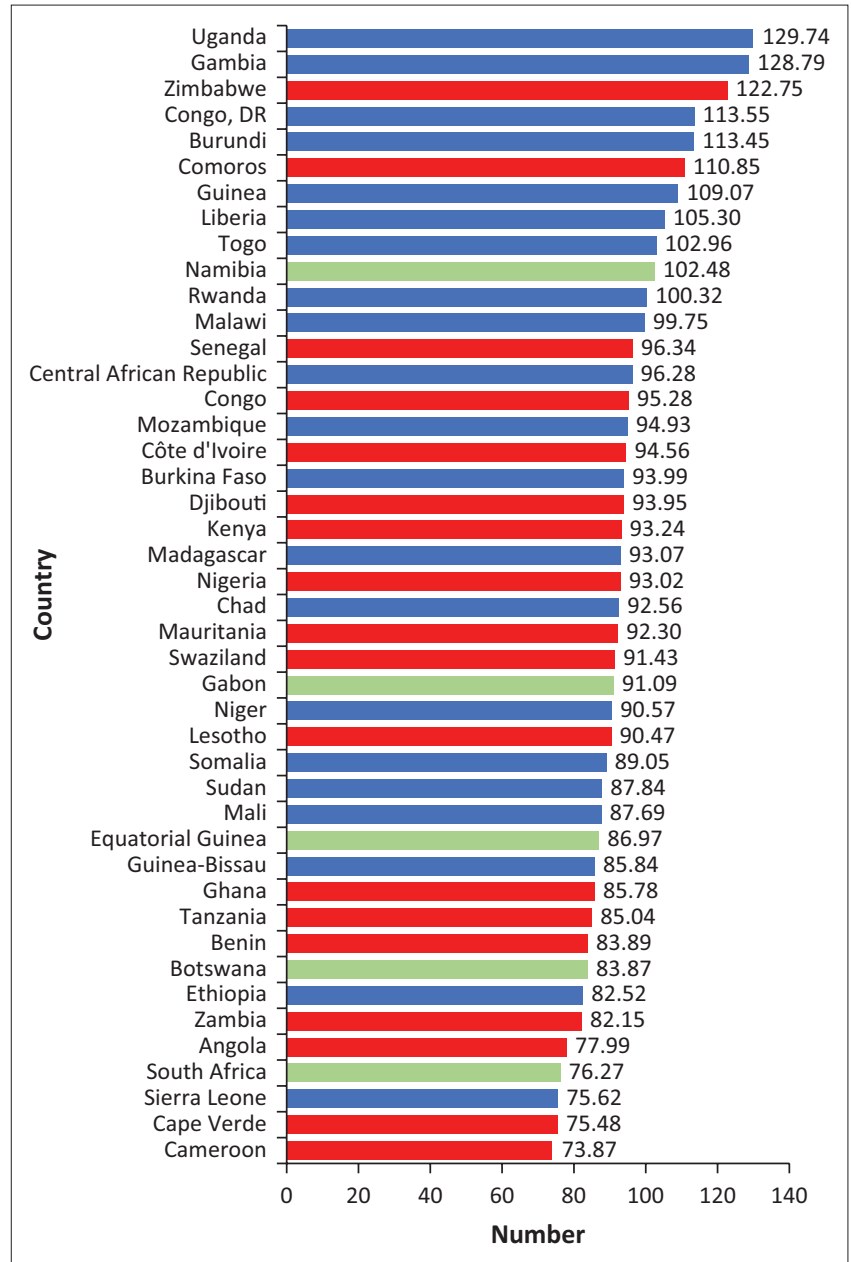

Note: Blue bars show low-income countries, green represent upper middle-income countrie and red bars lower middle-income countries.

*Productivity values in ('000').

FIGURE 1: Average agricultural productivity in sub-Saharan Africa, 1990-2014.

TABLE 4: World Bank classification of sub-Saharan Africa countries grouped by income levels.

Income group

Low-income sub-Saharan African Countries

Lower-middle income

sub-Saharan African Countries

Upper-middle income

Source: Adapted from World Bank, 2021, World Bank Country and Lending Groups, viewed 01 August 2021, from https://datahelpdesk.worldbank.org/knowledgebase/articles/ 906519-world-bank-country-and-lending-groups

subscribing to a mobileconnection. This estimate supports the idea that mobile technology has been significant in driving agricultural productivity in sub-Saharan Africa.

\section{Control variables}

Turning to the results of the control variables, we find that HIV and human capital have a negative impact on agricultural productivity. However, the refugee population ratio and infrastructure have no significant impact on agricultural productivity. 


\section{Robustness tests}

\section{Alternative estimation technique}

In testing the robustness of our results to an alternative estimation technique, we momentarily drop the LSDV technique and ensure spherical disturbances through a different method. Specifically, we employ the Pooled Ordinary Least Squares (POLS) method and adjust for heteroscedasticity and autocorrelation through the NeweyWest standard errors (Newey \& West 1987). Using the Hausman test (Hausman 1978), POLS and LSDV are compared and the result recommends the rejection of the null hypothesis that POLS is consistent. Consequently, the results of the POLS method may not be unaffected by endogeneity bias, possibly due to the omission of the country fixed effects. Unsurprisingly, the result obtained from the POLS technique is slightly different from that of the LSDV method. Using the POLS technique, the positive impact of mobile phone subscription on agricultural productivity reduces marginally to $11 \%$ at $5 \%$ significance level (Table 5, column 2).

\section{Impact of mobile technology on agricultural productivity by income groups}

Following the World Bank (2021) classification of countries by income levels, we split our sample into low income, lowermiddle income, and upper-middle income sub-Saharan African countries (See Table 4). The World Bank defines lowincome economies as those with a Gross National Income (GNI) per capita of $\$ 1045$ or less; lower middle-income with GNI per capita between $\$ 1046$ and $\$ 4095$; upper middleincome with GNI per capita between \$4096 and \$12 696 . Subsequently, we investigate the extent to which the results vary across income levels, using the LSDV technique.

In the low-income sub-Saharan African countries, agricultural productivity rises by $29.8 \%$ with one additional person subscribing to a mobile phone (Table 6, column 1). Also, in the case of the lower-middle income sub-Saharan African countries, a similar increase in mobile subscriptions impacts positively on agriculture by about $16.5 \%$ (Table 6 , column 2 ). The results obtained for low-income and lower-middle income sub-Saharan African countries are statistically significant at a $1 \%$ level. However, the positive impact of mobile subscription is notably higher in the case of the former. Moving on to the result obtained for the uppermiddle income sub-Saharan African countries, we find that phone subscription does not have a statistically significant impact on this group of countries.

\section{Controlling for countries with low total factor productivity}

As part of our sensitivity analysis, we utilise the LSDV method to investigate whether our results are driven by some countries recording the lowest average agricultural productivity during the timeframe of this study (i.e. 1990-2014). To this purpose, we exclude from our sample, Cameroon, Cape Verde and Sierra Leone; thereafter, agricultural productivity is again regressed on our set of explanatory variables. The results obtained are very similar to those obtained in the baseline
TABLE 5: Pooled Ordinary Least Squares (POLS) and Least Squares Dummy Variables (LSDV).

\begin{tabular}{|c|c|c|}
\hline \multirow[t]{2}{*}{ Dependent variable: TFP } & 1 & 2 \\
\hline & LSDV & POLS \\
\hline \multirow[t]{2}{*}{ REFPROP } & 84.580 & $445.602 *$ \\
\hline & (404.131) & $(247.380)$ \\
\hline \multirow[t]{2}{*}{ MOBILE } & $0.127 * * *$ & $0.110 * *$ \\
\hline & $(0.039)$ & $(0.055)$ \\
\hline \multirow[t]{2}{*}{ HIV } & $-3.781 * * *$ & $0.947^{*}$ \\
\hline & $(0.465)$ & $(0.492)$ \\
\hline \multirow[t]{2}{*}{$\mathrm{HC}$} & $-58.699 * * *$ & -0.923 \\
\hline & $(15.804)$ & $(4.468)$ \\
\hline \multirow[t]{2}{*}{ CREDIT } & 0.002 & -0.002 \\
\hline & $(0.002)$ & $(0.008)$ \\
\hline \multirow[t]{2}{*}{ RESEXP } & -0.002 & 0.000 \\
\hline & $(0.003)$ & $(0.008)$ \\
\hline \multirow[t]{2}{*}{ INFRA } & 0.090 & -0.366 \\
\hline & $(0.132)$ & (0.229) \\
\hline \multirow[t]{2}{*}{ SAFELAW } & 0.091 & $-0.266 * *$ \\
\hline & $(0.117)$ & $(0.116)$ \\
\hline \multirow[t]{2}{*}{ LOG (EXCHANGE RATE) } & $4.234^{*}$ & 1.758 \\
\hline & $(2.100)$ & (1.268) \\
\hline \multirow[t]{2}{*}{ Constant } & $189.346 * * *$ & $109.494 * * *$ \\
\hline & $(25.718)$ & $(13.043)$ \\
\hline Observations & 198 & 198 \\
\hline Country FE & Yes & No \\
\hline Hausman (LSDV vs POLS): & - & 0.005 \\
\hline$P$-value & - & 18.56 \\
\hline Chi-squared & - & - \\
\hline
\end{tabular}

Note: Country FE signifies the inclusion, or otherwise, of the Country fixed effects. The parentheses contain the standard errors.

${ }^{*} p<0.10 .{ }^{* *} p<0.05 .{ }^{* * *} p<0.01$.

HIV, human immunodeficiency virus.

TABLE 6: Low income, lower middle and upper middle.

\begin{tabular}{|c|c|c|c|}
\hline \multirow{2}{*}{$\begin{array}{l}\text { Dependent } \\
\text { variable: TFP }\end{array}$} & 1 & 2 & 3 \\
\hline & $\begin{array}{l}\text { Low income } \\
\text { countries }\end{array}$ & $\begin{array}{l}\text { Lower middle } \\
\text { income }\end{array}$ & $\begin{array}{c}\text { Upper middle } \\
\text { income }\end{array}$ \\
\hline \multirow[t]{2}{*}{ REFPROP } & 249.131 & $-2700 * *$ & $84000 * * *$ \\
\hline & $(641.736)$ & $(922.582)$ & (7685.462) \\
\hline \multirow[t]{2}{*}{ MOBILE } & $0.298 * * *$ & $0.165 * * *$ & 0.013 \\
\hline & $(0.056)$ & $(0.034)$ & $(0.070)$ \\
\hline \multirow[t]{2}{*}{ HIV } & $-8.693 * * *$ & $-1.735 * *$ & -0.409 \\
\hline & $(0.442)$ & $(0.600)$ & $(2.240)$ \\
\hline \multirow[t]{2}{*}{$\mathrm{HC}$} & $-142.348 * * *$ & $36.730 * *$ & 57.808 \\
\hline & (13.233) & $(14.216)$ & (64.719) \\
\hline \multirow[t]{2}{*}{ CREDIT } & 0.002 & $-0.013 * * *$ & 0.000 \\
\hline & $(0.003)$ & $(0.002)$ & $(0.032)$ \\
\hline \multirow[t]{2}{*}{ RESEXP } & $-0.219 * * *$ & -0.004 & $-0.265 * * *$ \\
\hline & $(0.044)$ & $(0.003)$ & $(0.037)$ \\
\hline \multirow[t]{2}{*}{ INFRA } & 0.079 & $-1.120 * *$ & $-1.807 * *$ \\
\hline & $(0.352)$ & $(0.455)$ & $(0.685)$ \\
\hline \multirow[t]{2}{*}{ SAFELAW } & -0.229 & -0.063 & -0.264 \\
\hline & (0.414) & $(0.318)$ & $(0.202)$ \\
\hline \multirow[t]{2}{*}{ EXCHANGERATE } & $16.552 * * *$ & $9.166 * * *$ & 0.465 \\
\hline & (3.182) & (2.791) & (10.033) \\
\hline \multirow[t]{2}{*}{ Constant } & $277.917 * * *$ & 35.627 & 65.950 \\
\hline & $(23.150)$ & (23.125) & $(181.250)$ \\
\hline Observations & 86 & 83 & 29 \\
\hline$R$-squared (within) & 0.434 & 0.202 & 0.697 \\
\hline Country FE & Yes & Yes & Yes \\
\hline
\end{tabular}

Note: Country FE signifies the inclusion, or otherwise, of the Country fixed effects. The parentheses contain the standard errors.

${ }^{*} p<0.10 . * * p<0.05 . * * * p<0.01$

FE, fixed effects; TFP, total factor productivity; HIV, human immunodeficiency virus. 
TABLE 7: Accounting for countries with low total factor productivity (TFP), and inclusion of additional control variables.

\begin{tabular}{|c|c|c|}
\hline Dependent variable: TFP & Countries with low TFP & Inclusion of extra controls \\
\hline \multirow[t]{2}{*}{ REFPROP } & 84.580 & 117.685 \\
\hline & (404.131) & (394.321) \\
\hline \multirow[t]{2}{*}{ MOB } & $0.127 * * *$ & $0.125 * * *$ \\
\hline & $(0.039)$ & $(0.039)$ \\
\hline \multirow[t]{2}{*}{ HIV } & $-3.781 * * *$ & $-3.456 * * *$ \\
\hline & $(0.465)$ & $(0.469)$ \\
\hline \multirow[t]{2}{*}{$\mathrm{HC}$} & $-58.699 * * *$ & $-49.968 * * *$ \\
\hline & $(15.804)$ & $(13.635)$ \\
\hline \multirow[t]{2}{*}{ CREDIT } & 0.002 & 0.004 \\
\hline & $(0.002)$ & $(0.003)$ \\
\hline \multirow[t]{2}{*}{ RESEXP } & -0.002 & -0.002 \\
\hline & $(0.003)$ & $(0.004)$ \\
\hline \multirow[t]{2}{*}{ INFRA } & 0.090 & 0.177 \\
\hline & $(0.132)$ & $(0.158)$ \\
\hline \multirow[t]{2}{*}{ SAFELAW } & 0.091 & 0.088 \\
\hline & $(0.117)$ & $(0.133)$ \\
\hline \multirow[t]{2}{*}{ EXCHANGERATE } & $4.234 *$ & $6.363 * * *$ \\
\hline & $(2.100)$ & $(2.004)$ \\
\hline \multirow[t]{2}{*}{ LAND } & - & $0.001 * * *$ \\
\hline & - & $(0.000)$ \\
\hline \multirow[t]{2}{*}{ LAB } & - & $-0.001 *$ \\
\hline & - & $(0.000)$ \\
\hline \multirow[t]{2}{*}{$\mathrm{MACH}$} & - & -0.001 \\
\hline & - & $(0.000)$ \\
\hline \multirow[t]{2}{*}{ LOG(FERT) } & - & $-3.008^{*}$ \\
\hline & - & (1.594) \\
\hline \multirow[t]{2}{*}{ Constant } & $189.346 * * *$ & $187.152 * * *$ \\
\hline & $(25.718)$ & $(28.851)$ \\
\hline Observations & 198 & 198 \\
\hline$R$-squared (within) & 0.141 & 0.1621 \\
\hline Country FE & Yes & Yes \\
\hline
\end{tabular}

Note: Country FE signifies the inclusion, or otherwise, of the Country fixed effects. The parentheses contain the standard errors.

${ }^{*} p<0.10 .{ }^{* *} p<0.05 .{ }^{* * *} p<0.01$

$\mathrm{FE}$, fixed effects; TFP, total factor productivity; HIV, human immunodeficiency virus.

(Table 7, column 1). Consequently, the positive impact of mobile subscriptions is not driven by countries with a low level of agricultural productivity.

\section{Inclusion of additional control variables}

In this sub-section, we include in our model some control variables which have been proven in the literature to be drivers of agricultural productivity. These variables include land, labour machinery and fertiliser. The results obtained are not significantly different from those obtained previously (Table 7, column, 2)

\section{Conclusion and policy implications}

This research investigates the contribution of mobile phone technology and its impact on agricultural productivity in SSA. This research work, to the best of our knowledge, is the first to report evidence suggesting that the adoption of mobile phone technology is also a driver of agricultural productivity in SSA. A method employed by Fuglie and Rada (2013) was used to explain changes in agricultural TFP growth in SSA. These variables were regressed against TFP to explain the changes in agricultural TFP growth.
Our result indicates that mobile technology enhanced and contributed to agricultural TFP growth in SSA. The use of mobile phone technology helped farmers to access information on prices and logistics, and even assisted them in entering new markets. It also allows the transfer of information between rural areas and core markets.

The negative impact of HIV on agricultural productivity suggests that adequate measures should be taken to reduce the spread of it, as it affects the number of people available for agricultural work, in terms of those affected by the disease, and because family members and friends spend otherwise productive time looking after them.

According to WDI (2017), the SSA region is the poorest region in the world. There is an urgent need to rescue this region from its present precarious situation. The World Development Report (2008) states that growth in the agricultural sector has double the potential of other sectors to reduce poverty. Riaz (1997) observed that significant improvements in the telecommunications infrastructure in Malaysia, aided not only agricultural productivity, but also a successful economic transformation. Corroborating this, Madden and Salvage (1998) reported that failure to advance telecommunication infrastructure in the transitional economies of countries in Central and Eastern Europe led to a decline in trade performance and regional productivity. Since mobile phone technology has been found to be positively related to agricultural TFP growth, and there is evidence that telecommunication infrastructure helped to revive weak economies, it is only reasonable that investments in mobile telephony be increased and sustained with the aim of increasing agricultural productivity and, eventually, economic growth.

\section{Study limitations}

This research work is limited in terms of data availability. We relied on secondary sources of data; data on a national level for a set of predominantly developing economies where resources devoted to data collection are low which might consequently give rise to estimation issues. Our model estimations were inevitably limited in terms of obtaining a set of consistent time series across all the variables which, as hypothesized might influence agricultural productivity. This study paves the way for further studies to employ other methods such as parametric and non-parametric methods, to measure agricultural productivity and to explore other drivers of productivity.

\section{Acknowledgements Competing interests}

The authors declare that they have no financial or personal relationships that might have inappropriately influenced them in writing this article.

\section{Authors' contributions}

O.A was involved in the conceptualisation of the study, literature review, data analysis, presentation and interpretation 
of results. O.T. was involved in reviewing the analysis, the write up and the manuscript. A.I. provided quantitative expertise during the review process with a modification to the data analysis and interpretation of results.

\section{Ethical considerations}

This article followed all the ethical standards for research without direct contact with human or animal subjects.

\section{Funding information}

This research received no specific grant from any funding agency in the public, commercial, or not-for-profit sectors.

\section{Data availability}

The data used in the study were obtained from the FAO, the World Bank, United Nations Human Development Data, the Next Generation of the Penn World Table, the International Labour Organization (ILO) and the United States Department of Agriculture (USDA) Economic Research Service statistical databases.

\section{Disclaimer}

The view and opinions expressed in this article are those of the authors and do not necessarily reflect the official policy or position of any affiliated agency of the authors.

\section{References}

Aker, J.C., 2008, Does digital divide or provide? The impact of cell phones on grain markets in Niger, viewed n.d., from https://www.cgdev.org/publication/does-digital-divideor-provide-impact-cell-phones-grain-markets-niger-working-paper-154.

Aker, J.C. \& Mbiti, I.M., 2010, 'Mobile phones and economic development in Africa', The Journal of Economic Perspectives 24(3), 207-232. https://doi.org/10.1257/ jep.24.3.207

Antle, J.M., 1983, 'Infrastructure and aggregate agricultural productivity: International evidence', Economic Development and Cultural Change 31(3), 609-619.

Asenso-Okyere, K. \& Mekonnen, D.A., 2012, 'The importance of ICTs in the provision of information for improving agricultural productivity and rural incomes in Africa', African Human Development Report, UNDP Sponsored research Series.

Barrios, E.B., Joseph Ryan, G. \& Daquis, J.C.P., 2011, 'Impact assessment of the e-AGRIKultura project: Philippines', in D.J. Grimshaw \& S. Kala (eds.), Strengthening rural livelihoods: The impact of information and communication technologies in rural livelihoods: The impact of information and communicatic pp. 89-108, Practical Action Publishing, Warwickshire.
Asia,

Block, S.A., 1994, 'A new view of agricultural productivity in sub-Saharan Africa', American Journal of Agricultural Economics 76(3), 619-624. https://doi. org/10.2307/1243676

Brynjolfsson, E. \& Hitt, L.M., 2000, 'Beyond computation: Information technology, organizational transformation and business performance', Journal of Economic Perspectives 14(4), 23-48. https://doi.org/10.1257/jep.14.4.23

Chilonda, P. \& Otte, J., 2006, 'Indicators to monitor trends in livestock production at national, regional and international levels', Livestock Research for Rural Development 18(8), 117

Coelli, T.J. \& Rao, D.P., 2005, 'Total factor productivity growth in agriculture: A Malmquist index analysis of 93 countries, 1980-2000', Agricultural Economics 32(s1), 115-134. https://doi.org/10.1111/j.0169-5150.2004.00018.x

Coelli, T.J., Rao, D.S.P., O’Donnell, C.J. \& Battese, G.E., 2005 An introduction to efficiency and productivity analysis, Springer Science \& Business Media, New York, NY.

Dixon, S., McDonald, S. \& Roberts, J., 2002, 'The impact of HIV and AIDS on Africa's economic development', BMJ: British Medical Journal 324(7331), 232. https://doi. org $/ 10.1136 / \mathrm{bmj} .324 .7331 .232$

Driscoll, J.C. \& Kraay, A.C., 1998, 'Consistent covariance matrix estimation with spatially dependent panel data', Review of Economics and Statistics 80(4), 549-560. https://doi.org/10.1162/003465398557825
Fengying, N., Li, Z., Jieying, B., Fujiang, L. \& Xiaochao, T., 2011, 'Evaluation of a rural information project in Ningxia, China', in D.J. Grimshaw \& S. Kala (eds.) Strengthening rural livelihoods: The impact of information and communication Strengthening rural livelihoods: The impact of info
technologies in Asia, pp. 109-132, Warwickshire.

Food and Agriculture Organization of the United Nations (FAO), 2017, Information and Communication Technology (ICT) in agriculture: A report to the G20 Agricultural Deputies, viewed from http://www.fao.org/3/a-i7961e.pdf.

Fuglie, K. \& Rada, N., 2013, Resources, policies, and agricultural productivity in subSaharan Africa, viewed from https://ageconsearch.umn.edu/bitstream/145368/2/ err145.pdf.

Fuglie, K.O. \& Rada, N.E., 2012, 'Constraints to raising agricultural productivity in subSaharan Africa', in K. Fuglie, S.L. Wang \& V.E. Ball (eds.), Productivity growth in agriculture: An international perspective, pp. 237-272, CPI Group Ltd, Croydon.

Hausman, J., 1978, 'Specification tests in econometrics', Econometrica 46(6), 12511271. https://doi.org/10.2307/1913827

Heshmati, A. \& Kumbhakar, S.C., 2011, 'Technical change and total factor productivity growth: The case of Chinese provinces', Technological Forecasting and Social Change 78(4), 575-590. https://doi.org/10.1016/j.techfore.2010.11.006

Katengeza, S.P., Okello, J.J. \& Jambo, N., 2011, 'Use of mobile phone technology in agricultural marketing: The case of smallholder farmers in Malawi', International Journal of ICT Research and Development in Africa (IJICTRDA) 2(2), 14-25. https:// doi.org/10.4018/jictrda.2011070102

Lum, T., 2011, 'Mobile goes global: The effect of cell phones on economic growth and development', Honours thesis, viewed 02 July 2018, from http://digitalcommons. bucknell.edu/honors_theses/4.

Lusigi, A. \& Thirtle, C., 1997, 'Total factor productivity and the effects of R \& D in African agriculture', Journal of International Development 9(4), 529-538. https://doi. org/10.1002/(SICI)1099-1328(199706)9:4\%3C529::AID-JID462\%3E3.0.CO;2-U

Lokanathan, S., De Silva, H. \& Fernando, I., 2011, 'Price transparency in agricultura produce 27 markets: Sri Lanka', in D. J. Grimshaw \& S. Kala (eds.), Strengthening rural livelihoods. The impact of information and communication technologies in Asia, pp. 15-32, Practical Action Publishing Ltd, Warwickshire.

Madden, G., \& Savage, S. J., (1998), 'CEE telecommunications investment and economic growth', Information Economics and Policy, 10(2), $173-195$

Mittal, S., Gandhi, S. \& Tripathi, G., 2010, Socio-economic impact of mobile phones on Indian agriculture, Indian Council for Research on International Economic Indian agriculture,
Relations, New Delhi.

MO Ibrahim Foundation, 2017, Ibrahim Index of African Governance, viewed 02 July 2018, from http://mo.ibrahim.foundation/iiag/.

Muto, M. \& Yamano, T., 2009, 'The impact of mobile phone coverage expansion on market participation: Panel data evidence from Uganda', World Development 37(12), 1887-1896. https://doi.org/10.1016/j.worlddev.2009.05.004

Newey, W.K. \& West, K.D., 1987, 'A simple, positive semi-definite, heteroskedasticity and autocorrelation consistent covariance matrix', Econometrica 55(3), 703-708. https://doi.org/10.2307/1913610

Nnadi, F.N., Chikaire, J., Atoma, C.N., Egwuonwu, H.A. \& Echetama, J.A., 2012, 'ICT for agriculture knowledge management in Nigeria: Lessons and strategies for improvement', Science Journal of Civil Agricultural Research and Management 2012, 8. https://doi.org/10.7237/sjarm/192

OECD/FAO, 2016, OECD-FAO agricultural outlook 2016 - 2025, OECD Publishing, Paris.

Perez-Estebanez, R., Urquía-Grande, E. \& Rautiainen, A., 2017, 'Technological and economic factors determining ICT level: Evidence from rural micro-businesses in Democratic Republic of Congo', Journal of International Development 30(s1), in Democratic Republic of Congo', Journal of
$118-133$. https://doi.org/10.1002/jid.3281

Raj, D.A., Murugesan, A.P., Aditya, V.P.S., Olaganathan, S. \& Sasikumar, K., 2011, 'A crop nutrient management decision support system: India', in D.J. Grimshaw \& S. Kala (eds.), Strengthening Rural Livelihoods: The impact of information and S. Kala (eds.), Strengthening Rural Livelihoods: The impact of information and
communication technologies in Asia, pp. 33-52, Practical Action Publishing and communication technologies in Asia, pp. 33-52, Practical Action
International Development Research Centre, Rugby and Ottawa.

Riaz, A., 1997, 'Telecommunications in economic growth of Malaysia', Journal of Contemporary Asia 27(4), 489-510. https://doi.org/10.1080/00472339780000291

Rizvi, S.H., 2011, 'LifeLines: Livelihood solutions through mobile technology in India', in D.J. Grimshaw \& S. Kala (eds.), Strengthening rural livelihoods: The impact of information and communication technologies in Asia, pp. 53-70, Practical Action Publishing, Warwickshire.

Thirtle, C., Hadley, D. \& Townsend, R., 1995, 'Policy-induced innovation in sub-Saharan African agriculture: A multilateral Malmquist productivity index approach', Development Policy Review 13(4), 323-348. https://doi.org/10.1111/j.1467-7679. 1995.tb00097.x

Wolfert, S., Ge, L., Verdouw, C. \& Bogaardt, M.J., 2017, 'Big data in smart farming- A review', Agricultural Systems 153, 69-80. https://doi.org/10.1016/j.agsy.2017.01.023

World Bank, 2017, Data bank, viewed 27 February 2018, from http://databank. worldbank.org/data/home.aspx.

World Bank, 2021, World Bank Country and Lending Groups, viewed 01 August 2021 from https://datahelpdesk.worldbank.org/knowledgebase/articles/906519world-bank-country-and-lending-groups.

World Development Report, 2008, What can agriculture do for development? viewed n.d., from http://www.evidenceondemand.info/world-development-report2008-agriculture-for-development.

World Development Indicators, 2017, Statistical data base, viewed 27 February 2018 from https://data.worldbank.org/. 